49 | 2018

Human-environment relationships in Siberia and Northeast China. Knowledge, rituals, mobility and politics among the Tungus peoples, followed by Varia

The folks next door. Russian settlers and Evenki of the upper flow of the Lower Tunguska ( $19^{\text {th }}$-early $21^{\text {st }}$ century)

Les gens d'à côté. Les colons russes et les Évenks du cours supérieur de la Toungouska Inférieure (XIX'e-début XXI ${ }^{e}$ siècle)

Anna A. Sirina

Translator. J. M. Sutton

(2) OpenEdition

Journals

Electronic version

URL: https://journals.openedition.org/emscat/3221

DOI: 10.4000/emscat.3221

ISSN: 2101-0013

Publisher

Centre d'Etudes Mongoles \& Sibériennes / École Pratique des Hautes Études

Electronic reference

Anna A. Sirina, "The folks next door. Russian settlers and Evenki of the upper flow of the Lower

Tunguska (19th-early $21^{\text {st }}$ century)", Études mongoles et sibériennes, centrasiatiques et tibétaines [Online],

49 | 2018, Online since 20 December 2018, connection on 13 July 2021. URL: http://

journals.openedition.org/emscat/3221 ; DOl: https://doi.org/10.4000/emscat.3221

This text was automatically generated on 13 July 2021.

(c) Tous droits réservés 


\section{The folks next door. Russian settlers and Evenki of the upper flow of the Lower Tunguska $\left(19^{\text {th }}\right.$-early $21^{\text {st }}$ century)}

Les gens d'à côté. Les colons russes et les Évenks du cours supérieur de la Toungouska Inférieure (XIX ${ }^{e}$-début XXI ${ }^{e}$ siècle)

Anna A. Sirina

Translation : J. M. Sutton

\section{EDITOR'S NOTE}

Map of the repartition of the Evenki in Russia and China

click here

Positions of the case studies in the present volume

click here

\section{AUTHOR'S NOTE}

Translated from Russian by J. M. Sutton.

1 The study of the interrelations of Russian settlers with Asiatic peoples is amongst the problematic questions concerning the colonisation of Siberia (since the beginning of the $17^{\text {th }}$ century). The opinion has been expressed in the literature that Russians consider the Northern peoples radically distinct from themselves (slezkin 2008, p. 438). Is the history of interrelations between ordinary Russians and Evenki a history of alienation? Literature on this question, especially in relation to South Siberia, has 
appeared in recent years (Buraeva 2005, Gemuev \& Sagalaev 1986, Marhinin 1993, Gemuev \& Badmaev 2002, Karih 2004).

2 Contacts between Russian settlers and Evenki in the upper reaches of the large Siberian rivers and their tributaries, the Yenisei, Lower and Stony Tunguska, the river Lena and Upper Angara have been rather poorly studied. This is not surprising as the lands settled by the first Russians in the Yenisei-Angara region have been destroyed by the construction of hydropower stations along the river Angara at Irkutsk (1959), Bratsk (1967), Ust'-Ilimsk (1979), and Boguchansk (2014).

3 In this paper, based on fieldwork, archive, statistical materials and the literature, I study the interrelations of Evenki (until the end of the 1920s known as Tungus) and Russian settlers in the upper reaches of the river Lower Tunguska (the present day Katangskii district; Irkutsk region, Ru. oblast') in the period $19^{\text {th }}$ to early $21^{\text {st }}$ centuries.

$4 \quad$ I have spent many years doing fieldwork along the Lower Tunguska, the Evenki being the main focus of my attention. This group of Evenki are peculiar for their high level of assimilation as a result of historical contacts with Russian settlers and the Yakut population ${ }^{1}$. Processes of inter-ethnic interaction were also not without considerable reverse influence on both Russian settlers and Yakut. Relatively stable in numbers, these three ethnic groups made up the permanent population of the region where, until the mid- $20^{\text {th }}$ century, there was practically no influx from outside ${ }^{2}$. As a result, a unique ethno-cultural environment formed in the upper reaches of the Lower Tunguska. The following biographies of people of Russian self-identification who live in the district might be of great interest from the point of view of deep-set memory. Put briefly, they show the complex nature of local Russian ethnicity, based upon longestablished inter-ethnical marriages and cultural relations between Russians, Evenki and other nationalities.

Raida Evseevna Ineshina, b. 1915. Her grandfather on her father's side, Semën Aaronovich Rolbent, a Jew, was a political exile in Bodaibo, where he had his family. Jewish merchants of Bodaibo "recruited" him as their salesclerk to Lower Tunguska for the exchange of goods for furs for which they were in "hot pursuit" in those days. Semën Rolbent married here for the second time to Natalia (or Daria) Sychegir, a metis from Teteia whose father was Russian (according to family legend, some kind of merchant), and mother an Evenki. They had three sons: Evsei (future father of Raida and five other children), Mihail and Egor. Egor was brought up by childless Evenki, the Boiarshins, relatives of the Sychegir. Raida Evseevna Rolbent married a Russian settler, Alexei Denisovich InEshin (1913-1986) from Nepa. They got to know one another in the Evenki settlement of Diavdiavdiak where Alexei Ineshin came to eradicate illiteracy.

Vladimir Gavrilovich (family left unknown, officially Russian), b.1944, of Preobrazhenskoe settlement relates: "I was left an orphan of an Evenki mother at the age of two. My father was Russian: it seems he begot me of my mother. I was brought up by my grandpa, Nikolai Petrovich, he was closer than my mother. This grandfather lived in the forest and had up to 40 head of reindeer, and when the collective farms were formed, he had up to 30 kolkhoz deer. Grandpa married a second time, and my stepmother, Anisia Ivanovna, was half-Yakut. I lived with them till the seventh year at school: Grandpa didn't let me go to boarding school in Erbogachën. I went to a four-year school in the village of Iur'eva. At that time I lived in a Russian log cabin with Russian acquaintances, man and wife, who went off for the winter to hunt in the forest on reindeer together with grandpa. I grew up and worked in the geological expeditions; I work as a stoker now, also in the geological expeditions. My wife, Zoia Innokent'evna, is Russian. We have seven children". (fieldnotes 1988, 2008) 


\section{Ethnic composition, population size and settlement pattern over the period $19^{\text {th }}$-beginning $20^{\text {th }}$ century}

5 The first outsiders of the first half of the $17^{\text {th }}$ century to penetrate the taiga of Central Siberia from the river Yenisei were service people after the fur tax (yasak; Ru. iasak) that they collected from the indigenous peoples of the area, the Tungus (Evenki) (Dolgih 1960, pp.167-171). In 1911, old locals explained to the hydrologist V. Ia. Shishkov: "It was the Tunguska that opened up the Lena. It's older than the Lena. Cossacks came for 'yasak' from the Yenisei, not from the Lena" (Shishkov 1985, p. 399). Settlement occurred along the large Siberian rivers and their tributaries and portages: the shortest overland route from one river system to another. Over the first half of the $17^{\text {th }}$ century there were armed clashes between the Tungus and Russian fur traders inundating the taiga in search of valuable sable (Brodnikov 2006). The Russian administration in Siberia introduced a yasak collection system by taking the "best" Tungus into hostage. In order to do this a number of yasak log cabins were built in the upper and middle reaches of the river Lower Tunguska.

Figure 1. The geographical position of the Katanga district (raion) of Irkutsk province (oblast')

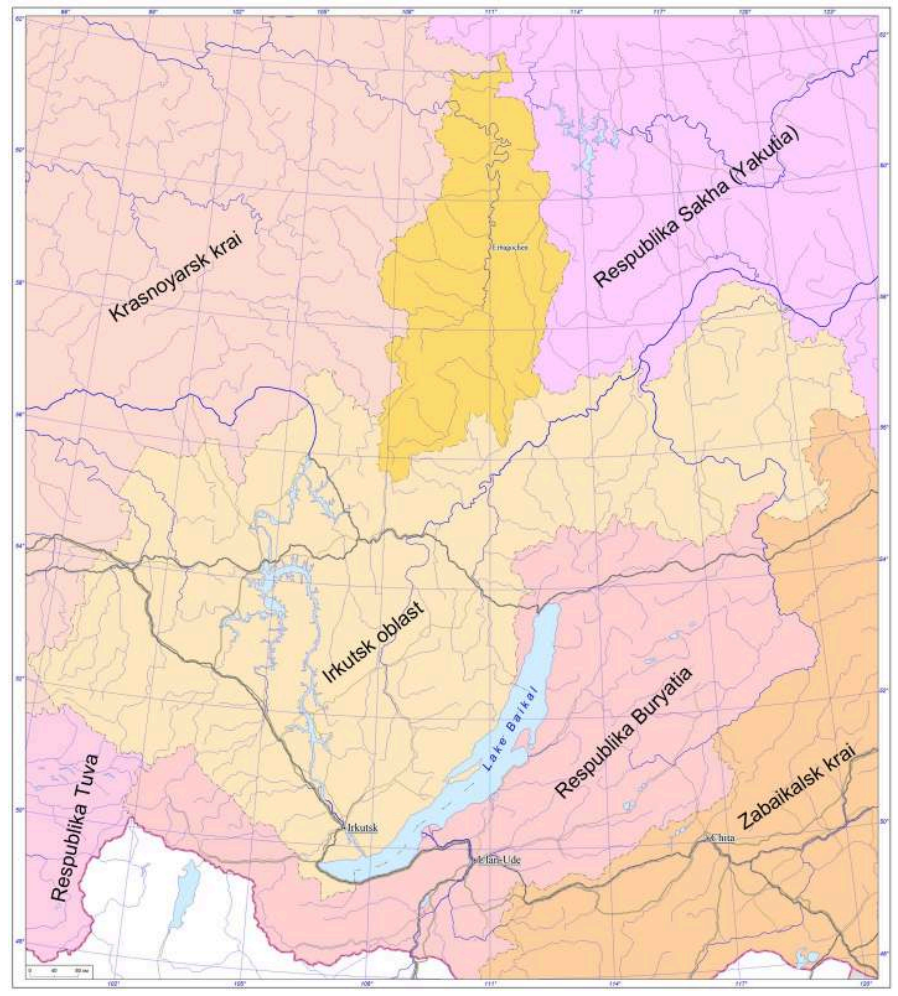

(c) A. Sirina and Ts. Dashpilov 
Figure 2. Population composition of the Katanga region

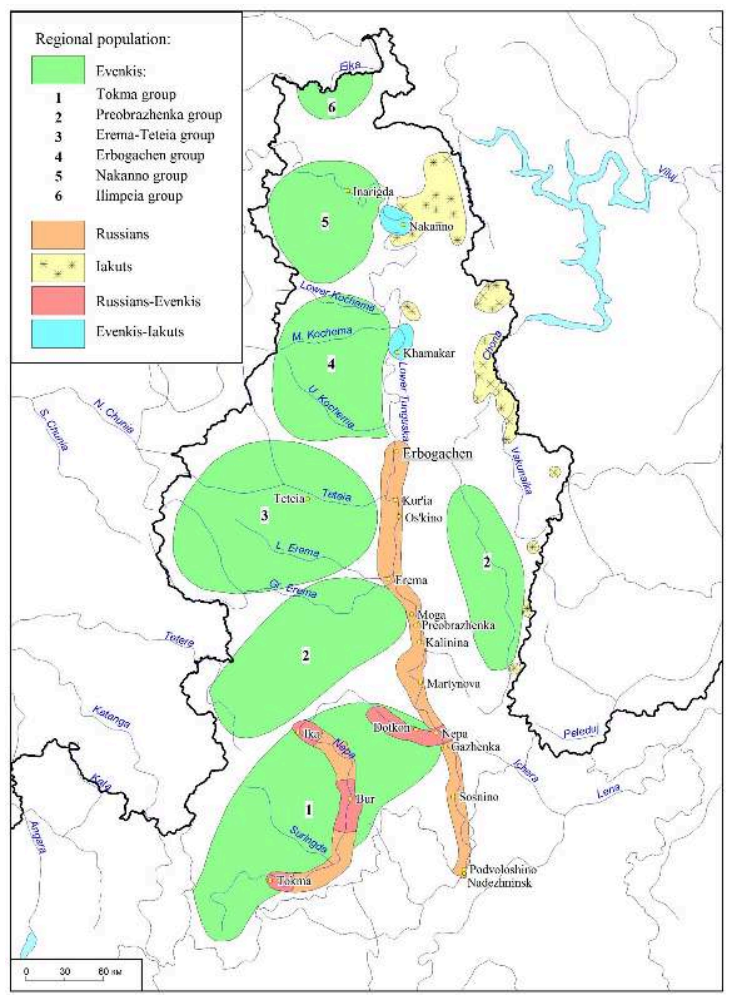

(C) A. Sirina and Ts. Dashpilov

\section{The Tungus (Evenki)}

The Tungus (Evenki) of the upper reaches of the Lower Tunguska were registered in the Kureisk and Kondogirsk non-Russian administrative councils set up in accordance with Speranskii's reforms in 1822 for governing proposes. Administratively they belonged to Preobrazhenskii portage in the Kirensk district (Ru. uezd) of Irkutsk Province, as did Russian peasants.

The Kureisk non-Russian administrative council, with its centre in the Russian village of Iurieva, incorporated the Tungus of the most upper reaches of the Lower Tunguska and its tributaries; some of the Tungus of this council migrated along the tributaries of the river Vitim. Their neighbours in the south and south-west were Russian settlers of the Lower Tunguska and Lena, and also a group of Kirensk Tungus, in the north - the Kondogirsk Tungus, in the north-east - Yakut, in the east and south-east - the Bodaibinsk Tungus and Yakut (see Fig. 2). The Kondogirsk council incorporated the Tungus that migrated to the north of Preobrazhenskoe right up to the mouth of the river Ilimpeia (i.e. to the beginning of the midstream of the Lower Tunguska). Their neighbours in the south and south-east were Kureisk Tungus, in the east - Viliuisk Tungus (assimilated into the Yakut to a high degree) and Yakut, and in the west Kezhemsk Tungus of the Yeniseisk county (Ru.okrug). In 1837, there were 752 Tungus in both administrative councils, in 1880 - 785, and in 1897 - 596 (ISRA 729/1/1, 729/1/5, pp. 1, 12, Patkanov 1906). Most Evenki kept their clan names, but had Russian surnames given at baptism (Sirina 2006). 


\section{Russian settlers}

8 Russian settlement of the Lower Tunguska took shape over the $17^{\text {th }}$ and $18^{\text {th }}$ centuries and consisted mainly of Cossacks and monastery peasants from Russia's northern provinces (Aleksandrov 1964, Bunak \& Zolotareva 1973). The peasants of upper Lower Tunguska were attached to the Turuhansk Trinity monastery that they supplied with grain (RGSSA 55(Б)/1/62, pp.70-72). At the end of the $19^{\text {th }}$-first quarter of the $20^{\text {th }}$ century, peasant penetration to upper Lower Tunguska expanded from the river Lena that was already overpopulated from the point of view of the fur trade (Kopylov et al. 2009).

9 At the end of the $19^{\text {th }}$ century, there were approximately 1,600 Russians in Preobrazhenskaia district of Kirenskii county in Irkutsk Province with its centre in the settlement of Preobrazhenskoe. Some 300 persons should be added to the numbers in Table 1. These are people living in the villages of Bur (Kuzakovy and Hromovy), and Tokma (Gordeevy) on the river Nepa, in the settlement of Podvoloshino (Piniginy) and villages of Upper- and Lower- Korelino (Koreliny) on the Lower Tunguska.

Table 1. The distribution, population and family size of Russian settlers along the upper course of the Lower Tunguska River, 1880

\begin{tabular}{|c|c|c|c|c|c|}
\hline \multirow{2}{*}{ Village } & \multirow{2}{*}{$\begin{array}{l}\text { Number } \\
\text { households }\end{array}$} & \multicolumn{2}{|c|}{ Population } & \multirow{2}{*}{ Total } & \multirow{2}{*}{ Surnames } \\
\hline & & Male & Female & & \\
\hline Preobrazhenka & 17 & 57 & 53 & 110 & Zyrianov, Iuriev \\
\hline Iurieva & 18 & 53 & 54 & 107 & Iuriev \\
\hline Nizhnekalinina & 13 & 39 & 34 & 73 & Verhoturov \\
\hline Verhnekalinina & 22 & 62 & 73 & 135 & Verhoturov, Permiakov \\
\hline Bokovikova & 12 & 36 & 30 & 66 & Bokovikov \\
\hline Martynova & 6 & 24 & 22 & 46 & Ineshins, Diadkin \\
\hline Danilova & 7 & 22 & 16 & 38 & Diadkin, Novoseltsev \\
\hline Potemina & 2 & 7 & 6 & 13 & Permiakov, Bokovikov \\
\hline Nepa & 26 & 88 & 102 & 190 & Ineshin, Verhoturov \\
\hline Gazhenka & 6 & 16 & 20 & 36 & Zarukin \\
\hline Logashino & 2 & 5 & 4 & 9 & Ineshin, Vlasov \\
\hline Sosnina & 4 & 16 & 18 & 34 & Safiannikov, Iuriev \\
\hline Moga & 13 & 50 & 53 & 103 & Safiannikov \\
\hline
\end{tabular}




\begin{tabular}{|l|l|l|l|l|l|}
\hline Zhdanova & 11 & 35 & 39 & 74 & $\begin{array}{l}\text { Zhdanov, Iuriev, Balakshin, } \\
\text { Permiakov }\end{array}$ \\
\hline Erioma & 10 & 27 & 34 & 61 & Farkov, Mungalov \\
\hline Luzhki & 3 & 17 & 17 & 34 & Farkov \\
\hline Oskino & 13 & 48 & 44 & 92 & Farkov, Iuriev, Kladovikov \\
\hline Ankula & 4 & 7 & 11 & 18 & Kolesnikov \\
\hline Erbogachën & 5 & 18 & 20 & 38 & Farkov, Mungalov \\
\hline Total & 194 & 627 & 650 & 1277 & \\
\hline
\end{tabular}

The table is composed on the basis of the archival data: ISRA R50/9/106

(c) A. Sirina

10 In the 1880s, on average, nine-ten persons made up a household; by the end of the 1920s this had declined to six-seven persons (Bunak \& Zolotareva 1973, Kopylov et al. 2009). Marital ties went beyond the borders of Preobrazhenskaia volost' and even outside ethnic groups as marriages were contracted with Tungus, Yakut and representatives of other ethnic groups ${ }^{3}$. A continuous network of kinship and relations formed in the villages along the Lower Tunguska, Lena, Nepa and Kuta. This social landscape was one of the most important results of the settlement of this part of Siberia.

11 Yakut came to Lower Tunguska from the rivers Viliui, Chona, and Olenëk (SuntaroOlekminsk alien administration) where at the end of the $19^{\text {th }}$ century their population amounted to 2,613 persons (Patkanov 1912, p. 528). By 1926-1927, 80 Yakut were living along the Lower Tunguska. Nominally they were christened and had Russian surnames. Their kinship can be traced to the Yakut and Tungus of the rivers Chona and Viliui, to the Kondogirsk Tungus and in part to Russian settlers (Sirina 2006, pp. 36-37).

\section{Ethnic and cultural contacts}

12 As Lindgren noticed in Manchuria in the 1930s, contacts between Reindeer Evenki and Cossacks were established mainly along kindred, economic and religious channels (Lindgren 1938, see also Dumont, Wure'ertu and Xie in the volume).

\section{Mixed marriages}

The specificities of settlement and social and cultural connections meant that RussoEvenki marriages were contracted in the upper reaches of the Lower Tunguska, while Evenki-Yakut marriages took place further to the north. During the first stage, Cossack settlers married Tungus and Yakut women. However, in the first half of the $19^{\text {th }}$ century most peasant marriages were within their own communities.

In 1839, the marriage of the newly christened (see more about religion below) Tungus of Kondogirsk council, P. A. Farkov, and Fevronia Ivanova, daughter of a peasant of the village of Erioma, Ivan Ivanovich Farkov was contracted 
(ISRA 50/3/537:, p.11). In 1840, the peasant V.O. Ineshin of the village of Martynova married Evfrosinia of Nizhnekalinina, daughter of the Russian orthodox Yakut, Farkov. At the same time, the yasak Tungus, Tihon Petrov Iuriev, of the Russian orthodox faith, married Agrippina Ivanova, daughter of the peasant, Ivan Terent'evich Kladovikov (ISRA 50/3/544, pp. 254 rev., 255 rev.). In January 1856, a peasant of the village of Fëdorova, Ivan Fëdorov Verhoturov, member of the Orthodox Church, 20 years of age, contracted his first marriage with 20-year-old Alexandra, daughter of the yasak Tungus Kiprian Kaplin. A deportee of the village of Nizhnekalinina, E.P. Dolgih and a peasant of the same village, Verhoturov were guarantors. (ISRA 50/1/779)

It seems that mixed marriages were contracted in the environment of the least well-off population and/or non-complete families. The descendants of the third or fourth generation of mixed Evenki-Russian marriages usually integrated into the Russian culture and took on its value system, so one can speak of the transition of the process of assimilation. Thus, on the river Ilim, Evenki virtually "dissolved" in the Russian peasant population, some, by the beginning of the $20^{\text {th }}$ century, only kept the designation "yasak" (Hodukin 1924). Similar processes occurred along the river Chuna in Yeniseisk Province where groups of Russian settlers came into contact with Tungus. In 1914 there remained ten half-Russified Tungus families some of which had settled and some had continued a nomadic way of life (see more about the economic activity below) along the river Karabula (a tributary of the river Angara). Old-timers born in the 1840s still remembered their Tungus grandfathers, but they considered themselves Russian, though of the Tungus type; they lived a settled way of life, and practised arable farming, hunting and fishing (Chekaninskii 1914). In Argun banks of Northeast China, the historically short contact between Russian Cossacks, who had started to settle in the Three Rivers Area (Ru. Trëhrech'e) of China in the second part of the $19^{\text {th }}$ century and had emigrated after the 1917 Revolution into China, and Tungus did not lead to assimilation (Lindgren 1938, Kaigorodov 1970). Processes of interethnic mixing occurred slowly up into the mid- $20^{\text {th }}$ century.

Old timers along the Lower Tunguska sometimes know exactly, but more often suppose, the Evenki part in their "kinship", and that in the most "unscientific" way: by appearance.

"We are like the Evenki, while those (forefathers, A. S.) were even more like them".

(fieldnotes 2008)

\section{Guardianship}

The custom of taking orphaned children into family guardianship was practised along the Lower Tunguska.

Judging by records of families living is a specific parish", in 1880, "the Tungus orphans taken into guardianship", Leontii Petrov Salatkin (22 years of age) and Georgii Petrov Salatkin (14 years) lived in the families of two Russian brothers of the village of Martynova: the former, in the family of the widower, Vasilii Iosifovich Ineshin (58 years of age), and the latter in the family of Georgii Iosifovich Ineshin (53 years). At the same time, in the family of the widower Alexei Kiriakovich Farkov (47 years), in the village of Oskinska, there were six persons: the married son (25 years) with children and Tungus, 17 year-old Moisei Gerasimov, in guardianship. (ISRA 50/9/106, p. 368)

More rarely did Russians give up their children, or Tungus take Russian orphans into guardianship. Thus, the Turuhanskii priest, M. Suslov, gave his son Mihail to Tungus to 
be brought up, having established closer relations with them (Anderson \& Orekhova 2002, p. 89). Children were brought up in the cultural traditions of the "adopting" side, but they also had knowledge of their "blood" culture.

\section{Economic relations}

\section{they lived for a number of months each year. They gathered hay and were hired for} permanent wooden houses built with the help of Russian peasants and exiles where logging (Kopylov et al. 2009).

doption of items occurred not only by way of gifts, purchases or exchange, but also by taking on manufacturing ways. In the main, adoption by Russians of Evenki know-how took place in the field of hunting. This was multi-functional implements: a large knife sharpened on one side on a long pole (up to a metre long) handle (Evk. koto, Ru. palma) - and a diamond-shaped spear (Evk. gida); Evenki clothes and fur shoes; means of transport - skin-skis, and birch-bark boats and tableware. Characteristically, in areas of contact, Russians tried to obtain items that the Evenki made for themselves (Alekseenko 1986, pp. 86-87). A diet of uncooked plants (especially during the hunting season) was widespread; the skills of making unleavened bread in the ashes of a camp fire, the practice of eating ground fish with berries etc. arose (Strakach 1962). 

they did not give up their traditional beliefs of animism and shamanism. The Tungus honoured especially the Translation of the Relics of St Nicholas from Myra to Bari, $22^{\text {nd }}$ May, Petrov Den' (St Peter's Day), $12^{\text {th }}$ July, and Nikolin Den' (the Day of St Nikolas the miracle-worker), $19^{\text {th }}$ December, when they came out of the taiga to Russian villages for the exchange of furs and purchase of provisions. At this time they went to church where the sacraments of marriage, christening and funerals were performed.

M. I. Mungalova from the village of Preobrazhenskoe said that Evenki came from Stony Tunguska to the settlement for Petrov Den' and camped down on the high banks of the river in their portable "chums" (bark tents). Once, two Tungus women came on their knees for some two kilometres to Preobrazhenskoe church, and children, amongst whom was M. I. Mungalova, full of curiosity, ran after them and showed them where the way was shorter. Later they left "furs and shawls at the altar. By this they made vows" (fieldnotes 1989).

eligious syncretism was characteristic of Evenki of this region. They were respectful of objects of Christian symbolism. Icons were transported on special "initiated" white reindeer and transported shamanic ritual items that were not used for household service. In their homes they were placed in a sacral place. Evenki folklore was extended with notions of heaven and hell, which became associated with their traditional concepts of upper and lower worlds (Vasilevich 1969, p. 212, Sirina 1993, p. 188). Funeral rituals were also impacted with the transition from over-ground to 
underground burials with a cross on the grave. At the same time, Evenki killed a sacrificial reindeer and carried out their own rites. However, in small settlements with a mixed ethnic population, graveyards were arranged according to ethnic principles (Sirina 2006, p. 165).

\section{Popular Orthodoxy of local Russians}

The Nizhnetungusk Preobrazhenskaia church was situated in the settlement of Preobrazhenskoe, and the church of St Nikolas in Erbogachën. However, at the beginning of the $20^{\text {th }}$ century, V. Ia. Shishkov noted a lack of piety amongst the Russians of Lower Tunguska by comparison with central regions of Russia: "The people are superstitious: believe in evil spirit (Ru. susedka), and ride round their houses on crutches before the New Year (men!)" (Shishkov 1985, p. 401). Animistic elements in the world-view of Russians most likely revived thanks to life in the back of beyond and contacts with Evenki. Russian hunters knew prohibitions connected with hunting, behaviour in an Evenki home and the handling of fire. They would leave "sacrifices" powder, percussion caps and matches in the same places as Tungus did in order to have luck in the hunt. "Believe or don't believe, but you must leave these things", a Russian hunter explained his actions to me. And this was so in all areas where there was contact. In eastern Pribaikal region, in the Barguzin district, there are old Evenki campsites where Russian hunters always bring gifts for the spirit-master of the place, considering it to be Evenki (Basharov 2005, p. 96). Peasants looked on shamanism and the various hunting rituals with religious tolerance, curiosity and at the same time apprehension. This feature was characteristic everywhere in areas of Russo-Tungus contacts: on the river Chuna, and the Argun region in the north-west of Manchuria: "Cossack hunters sometimes witness performances when they stay at Tungus camps, and often take the opportunity of asking the shaman's advice" (Lindgren 1938, p. 619). I. Chekaninskii noted that, at the same time, "If sometimes a Siberian-peasant goes to a shaman with a request for him to use his shamanist art to solve a mystery of a lost horse or cow, to forecast the results of a hunt or fate of a persistent illness, then the role of the peasant in the ritual can be quite inactive" (Chekaninskii 1914, p. 75). Legendary tales about shamans are told today amongst the inhabitants of Lower Tunguska.

\section{Bonds through baptism}

Bonds through baptism were dominant in the $19^{\text {th }}$ century by comparison with interethnic marriage or guardianship. They imposed mutual commitments concerning different kinds of mutual assistance, exchange of goods or provisions and combined hunting on both sides.

A story has been recorded relating to Lower Tunguska about a shaman, N. Y. Boiarshin, the godparent [sic] of a Russian settler, N. I. Utkin of the village of Verhnekalinina, Katangskii district, Irkutsk region. They hunted together. Boiarshin said to Utkin: "While I'm alive, fear no one. Wherever you go, wherever you wander, only remember me. Later, I will die, but no one will harm you in the forest. I can see you, see where you go". (Afanas'eva-Medvedeva 2007, pp. 122-123)

31 Not infrequently Russian peasants and exiles became the godparents of Tungus. The Registers of Birth in the Preobrazhenskaia church on the Lower Tunguska, and to a 
lesser extent in the churches of Voskresenskaia in Chechuisk, Nikolaevskaia in Podkamenskoe, Spasskaia on the Vitim (all of which part of the Kirensk church administration) kept such records.

In 1858, seven-year-old Leontii, son of Petr Egorov Salatkin, "the christened Tungus of Kondogirsk non-Russian council". The peasant Verhoturov and his wife Ineshina of the village Verhnekalinina were the godparents. The godparents of Akulina, daughter of the Tungus Prokopii Petrov Salatkin of Kureisk non-Russian council, were "the peasant I. F. Bokovikov and his wife D. I. Diadkina of Bokovikova village". The godfather of the two-year-old son of the Tungus Kaplin, Evgraf, was a Kirensk "petit bourgeois" (Ru. meshchanin), D. A. Akulov (ISRA 50/3/802, p. 409 rev.). In 1862 , the christenings of nine "non-Russians" whose godparents were peasants from the settlements of Nepa, Nizhnekalinina, Erbogachën, Ankula and Iurievo were registered. (ISRA 50/3/837, pp. 154, 159, 160, 162)

It is noteworthy that the godparents of Tungus of the southern parts of what is now Katangskii district (formerly Kureiskii district, Ru. Kureiskaia uprava) were often peasants of Petropavlovsk parish, i.e. from the villages of Mutina, Ichëra, and others situated along the river Lena (ISRA 50/3/693, 730, 779, 802). The Tungus were given Russian names, while their own names also remained.

\section{Russian view of Evenki}

According to my field data, distinctive features of the relations between Russian settlers and Evenki in the sparse population around the Lower Tunguska were mutual tolerance, respect and cultural adoption. Russian settlers knew the culture and mode of life of their neighbours and some were able to use the spoken language. Here are some reminiscences of Russians born in the 1930s about Evenki:

"Evenki came to the village on reindeer and in summer in a birch-bark boat. They were made welcome and respected in every village, people like us - they were given tea. They would put up their chums near the village, drink tea and chat. Anna and Lëva would come to us and we would run over to them. They baked bread on the ashes of a camp fire. They were clean, the Evenki. They treated us to reindeer milk". (E. M. Iurieva, fieldnotes 2008)

"I remember one Evenki: Afonia-muzhichok. That's what they called him. With his wife. They used to come to us and stayed in our house with us. His wife was very skillful with her hands. And every time they came, they would bring dried meat, jerky meat, and fresh in abundance, and all sorts of reindeer skins. So, she would settle down at our place. The old man, of course, would wander around the village. But she would make herself comfortable, reindeer skins all around, deer skins, and she would make small decorative mats (Evk. kumalan), and all sorts of footwear. She made doeskins from deerskins. They called them sary, summer shoes ${ }^{6}$; also decorated with beads; she often made me these sary and high deerskin winter boots. She dressed me. She made them very well. Grandmother, Mother's mother, used to live with us. Once I came running in these sary; I'd been caught in the rain and they'd got wet. Grandma scolded me: "Look what you've done to them!" But I took them off, we washed them, rinsed them out and hung them up to dry. In the morning I took them and rumpled them up a bit and they became just as they had been. My word, she really made them well!". (V. A. Verhoturov, fieldnotes 2008)

"We were on friendly terms with the Evenki; they were very hard-working. They used to come to Iurievo to buy flour and provisions. All their clothes were of their own making; they made everything from skins. They processed shoes from the reindeer's leg-skin (Ru. kamus), and skins; the summer footwear (Evk. sary), were made from chamois leather (Ru. rovduga) (from deer or elk skin); they made slippers 
(Evk. gurumy) (winter footwear with long shanks, A. S.) and winter anoraks from deerskins. Russians would buy reindeer skin boots (Evk. torbasa); footwear sold well, and fur gauntlets and fur hats, the men would buy them; Ru. bitki (birch bark container) or basket for collecting berries, (Evk. guiavun, A.S.), and fur mat (Evk. kumalan) (widely known among local Russians, A. S.). Their unleavened bread (Evk. koloboie) made with deer milk without eggs, was very popular: the dough was kneaded and put in campfire ashes; later (when ready, A. S.) you blow off the ashes. They would stop not far from the village and treat us to all sorts: they hunted for a lot of elk and knew how to preserve and dry it: if the meat was fatty, it's taste was good. They used to fish, but they didn't keep cattle. They lived in chums covered in fur and birch bark. There was flooring and a campfire in the centre of the chum where they would prepare food and warm themselves. We were good neighbors then. (A. S. and E. F. Permiakovs, fieldnotes 2008)

In the first half of the $20^{\text {th }}$ century, as a result of the long history of living as neighbours and mutual contact, the population of the upper reaches of the Lower Tunguska grew close anthropologically and economically, as well as culturally. Awareness of themselves to a certain degree as a regionally single population developed. At the same time each of the ethnic groups kept the peculiarities of their own culture, stereotypes of behaviour and perception that are evidence of the stability of ethnic features.

\section{Peculiarities of interethnic contacts in the Soviet period}

The Soviet government carried out a social experiment in national, economic, cultural and religious spheres of life, intervening in people's everyday life.

Soviet national policy explained the difficult socio-economic and cultural state of the indigenous peoples of the North by the negative influence of the Russians and the former national policy; for this reason a course of political paternalism and national and cultural autonomy in relation to the former "non-Russian" peoples was taken since 1920s'.

In 1927, Katangskii district was declared to be Evenki national although the majority of the population within it was Russian. The Polar census of 1926-1927 registered 1,280 Evenki (651 Kureisk Evenki and 629 Kondogirsk Evenki), 2,500-3,000 Russians and 80 Yakut (Gurvich \& Dolgih (eds) 1970, pp. 442-443). The centre of the national district was moved from Preobrazhenskoe further to the north, to Erbogachën.

One of the first matters of the Committee for the North, set up in 1927 within the Kirensk district executive committee as a branch of the Central Committee, was the organisation of land-surveying with the aim of settling controversial land use questions between Russians and Evenki. Having worked in the southern part of the district, the surveyors noted the impossibility of transferring the practice of conventional surveying to northern conditions, and they also underlined the "historically formed traditions of land use, which it was impossible not to take into account" (Kopylov et al. 2009, pp. 20-21).

commissioners for the Committee for the North, going out to "localities" and acquainting themselves with the situation with land use at first hand, evaluated it as "untroubled". It was reported from the neighbouring district of Ust'-Kut about the inhabitants on the river Taiura that "[...] the attitude of non-Russians towards Russians and of Russians towards non-Russians is comradely [...] no exploitation of the Tungus by Russians has been noted [...] there is friendly and shared use of 
hunting grounds, but there is dissatisfaction regarding fishing grounds". (ISRA 528/1/25, p. 17)

And from Katangskii district, Verhnekatangskii non-Russian council it was reported that "It is particularly gratifying... [that] at the 'suglan' [Evenki assembly] nonRussians and Russians discussed non-Russian questions together and no particular national discord was noted though there were complaints about the grabbing of hunting grounds by Russians; however, it was discussed without malignance". (ISRA R-538/1/223, p. 60 rev.)

of kulaks, i.e. the liquidation of strong peasant households and the setting up of collective economic units. Collectivisation in the district began over the years 1926-1928. By 1936-1939 there were 21 kolkhozes with a population of 2,921 persons; some $50 \%$ of households had been collectivised (KDA 12/1/25). In the southern part of the district, on the strength of established traditions, the Evenki supported the setting up of mixed Russo-Evenki communes and artels (ISRA P-528/1/49, p. 10). By 1942 only three artels of the eight existing were Evenki (in the settlements of Teteia, Ust'-Chaika and Hodolkit), the remainder had mixed membership: Evenki-Yakut in the northern, and Russo-Evenki in the southern parts of the district (KDA 12/1/25).

41

way of life. According to the reminiscences of V. A. Verhoturov:

"Formerly, when I lived in Verhnekalinino until 1948, we had a lot of Evenki. I can remember Nikolai Amosovich; he had a lot of reindeer and a large family. One of his sons was two years older than me, but I caught up with him in the second class; that's where he remained, in the second class. That is, when school began, he would always tear off to the forest. His name was Mitrii, Dmitrii. I'm not sure, but I think his surname was Salatkin. So much time has passed. I'm 77 now. Well, this Nikolai Amosovich had a good herd of reindeer, and he was driven into the kolkhoz, like a lot of Evenki, but he didn't want to go there. Of course he didn't want that; he had such a herd. And I went there (to him, A. S.) twice, I was sent deliberately, so to speak, by the chairman of the kolkhoz. He always stopped up near the village. There was a small river there, the Kuria; and he would set up his summer camp by it. As soon as he came out of the taiga for the summer, they would send a messenger to him to present himself before the kolkhoz management board. But he didn't want to. And apart from them, a lot of other Evenki also [...] they wanted to get them all into the kolkhoz also. But in my opinion, they shouldn't have done that". (fieldnotes 2008) 
In 1953, the agglomeration of settlements began which was not welcomed by either Russians or Evenki and led to migration beyond the limits of the district. By the 1960s and 1970s the number of settlements in Katangskii district had decreased from 34 to 18 . This is how elderly people recollect that time when they were 20-25 years of age:

"There was Georgii Mosiagin then (secretary of the district Communist party, A.S.); he'd say some nonsense like "let's combine the kolkhozes". But they didn't combine, but sailed off to Tura. And the people fled off in all directions. They made rafts of their houses and sailed off. Everything collapsed in the village, though they had lived and lived there. And they took a dislike to holding down two jobs at a time. Young men were taken into the army instead of hanging around the village. Those that didn't go to the kolkhoz were sent off to open up new land: "we'll go to till the earth, just as the old-timers did". (E. G. Iurieva, fieldnotes 2008)

"They lived very well; grew grain. But later they decided to amalgamate the kolkhozes; so Verhnekalinina was combined with Bokovikova, resettled everyone from Nizhnekalinina and some sort of enmity arose and people went their own way. So now in this Nizhnekalinina, it was also known as Fëdorovo, it's all empty, and Bokovinkova is also empty; and very few people have remained in Kalinina. People went their own way: some to Tura, others live in Angarsk or Irkutsk. They live along the river Lena in Yakutsk, and in Mirnyi; everywhere people went their own way. I think they were wrong to start that agglomeration. Somehow people started to fall out with each other. I could see this happening before I went into the army. This amalgamation of the kolkhozes began in the ' $50 \mathrm{~s}$ in our area, and oh, people began to live badly, though before that the kolkhozes were friendly places".

(V. A. Verhoturov, fieldnotes 2008)

Evenki settled down in Russian villages or new settlements and the area of the taiga that they had used decreased. Some Evenki, not wanting to settle down and enter kolkhoz, went off to the Evenki Autonomous County (Ru.okrug) (now, the Evenki's municipal district in the Krasnoyarsk region boarders) under the leadership of their elders and shamans to continue a nomadic life. Katangskii district became the first of the regions from which Evenki arrived in Evenkia (63.8\% of all migrants) (Boiko \& Kostyuk 1992, p. 38).

In the 1960s, after the reorganization of the kolkhozes into hunting enterprises, traditional farming went into decline and at the same time the number of hunters of different nationalities increased. The taiga was officially divided into hunting areas. Expensive sable furs brought in $96 \%$ of the income of Katangskii's, and $94 \%$ of Preobrazhenskii's hunting enterprises in the 1980s (KDA 12/1/31, p. 46).

As in other spheres, the fundamentals of ethical interrelations between different ethnic groups remained in the sphere of sharing hunting grounds, products and goods. Because of increasing competition in the hunting trade, conflict often arose concerning the best sites, however, in actual fact, the traditional system of distribution on the basis of long-standing use and the support of fellow villagers has remained.

In the early 2000s, men earning a living in hunting, first and foremost the descendants of the early Russian settlers, raised the question of equalizing their status with those of minority Indigenous Peoples of the North on the basis that their historical roots are in the north and, like the indigenous peoples, they are dependent on the natural resources of their environment (Sirina 2006). In accordance with federal law from 30 July 2000: "On general principles on clan communities (Ru. rodovaia obshchina) of indigenous peoples of the North, Siberia and the Far East of Russian Federation organization", Evenki and Russians began to set up "clan communities", but the legal 
question of territories of traditional land use has still not been settled (Novikova \& Iakel' 2006, Sirina 2009, pp. 153-158).

Even today it is characteristic of the Evenki to give up ownership of property to aliens. Young wildlife management students who were sent to work in the district in the 1980s tried to spend their first hunting season together with Evenki and learnt skills from them. During the second season they usually hunted by themselves, often on Evenki hunting grounds (fieldnotes). The agreement between them on the allotment of the land during the hunting season was confidential. Russians, Evenki and Ket did the same on the river Sym.

I have seen the hunting dogs of amateur hunters at Evenki camps, kept according to unwritten agreement between their owners and the Evenki. People in settlements ask Evenki seamstresses to make them deerskin boots and hats. One or two Evenki families, when coming out of the taiga into a settlement where they have no accommodation, stay with their Russian acquaintances.

49 Both the locals and the newcomers come into contact easily if they can see mutual benefit from it. I happened to be an observer of such symbiotic mutually beneficial relations between geologists and Evenki and it was always on the basis of a common interest and love of hunting and everything connected with it. At the same time, alliances between Evenki-hunters and hunters of other nationalities were rarely longlived because of their differing attitudes to the trade.

Geological surveying had an impact on the numbers, structure, movements and contacts of the local population. At the end of the 1940s there was surveying for diamonds on the Lower Tunguska and Evenki worked as guides and reindeer-team drivers in the geological expeditions (see also Davydov 2013). In the 1970s and 1980s, geological expeditions based themselves in the settlements of Nadezhdinsk, Erbogachën, and Nakanno; numbers in the population increased from 6,000 in 1979 to 9,500 in 1989. Its composition changed, having become multiethnic. The number of mixed marriages between Evenki and incoming Russians, Belorussians, Ukrainians, Latvians and others increased. The children of one and the same mixed marriage can have different self-consciousness and assign themselves to different cultures. Marriages between the descendants of Russian settlers and newcomers of different nationalities became more frequent (Sirina 2006, pp. 56-57).

51 After the socio-economic crisis of the 1990s, the population of the district decreased by half: in 2008 there were 4,349 people living in Katangskii district of whom 2,246 lived in its centre. However, it was with the geology of the region that its future was linked. At the beginning of this century Verhnechonskii Oil and Gas Company, a daughter company of TNK-BP, and the Irkutsk Oil Company (INK) began work on the development of mineral deposits that had been prospected in Soviet times. Of the local inhabitants, a quota of 43 persons is involved in work at the extraction sites.

\section{Conclusion}

Each area of contact has its own specifics depending on the numbers, composition, and cultural peculiarities of the contact groups, influence of state policy and other factors. This question is of great interest to research, but, as noted by E. J. Lindgren, it is still very understudied. Groups of Sym, Ilim, Chuna, and Verhneangarsk Evenki underwent 
to differing degrees the process of acculturation and were assimilated by the Russian population as a result of historical contacts with Russian settlers. The same process occurred along the Lower Tunguska. It is important to note that the process of assimilation, from the historical and cultural point of view, is not one-sided and has formed a peculiar regional population. The population in places of similar contacts is mobile, has a great passion for hunting and has other characteristic peculiarities. The deep social transformations of soviet and post-soviet periods were not able to obliterate that which unites the local population: deep-set memory, the historical past and hunting as an occupation and way of life. The concept of deep-set memory should be further developed and used as a methodological tool rather than the ethnicity as such in the studies of the regions settled by a multinational population with a longterm mutual history.

However, the Evenki and the entire local community have proved to be open and defenceless in the face of the new economic order in the region: oil and gas extraction that has already taken its toll on the biological diversity of Katangskii district (so far limited to its southern part). Evenki and the local population, dependent on the products of hunting and fishing, are very vulnerable in the newly established situation; they do not have an effective mechanism for the defense of their interests. The personnel of the oil extraction industry work according to a shift system and the majority of shift workers are Russians from different parts of Irkutsk Oblast' and other regions of Russia. So the question of living side by side has taken on a new configuration: now it is life next door to oil rigs, shift workers and other newcomers.

BIBLIOGRAPHY

\author{
Abbreviations \\ ISRA - Irkutsk State Regional Archive. Located in Irkutsk. \\ KDA - Katanga District's Archive. Located in the village of Erbogachën, Katanskii raion, Irkutsk \\ Oblast'. \\ RGSSA - Russian Geographical Society Scientific Archive. \\ IEA RAS - Institute of Ethnology and Anthropology of Russian Academy of Sciences. \\ NGU - Novosibirskii Gosudarstvennyi Universitet [Novosibirsk State University]. \\ IG SB RAS - Institute of Geography, Siberian Branch, Russian Academy of Sciences. \\ BNTz SO RAN - Buriatskii Nauchnyi Tsentr Sibirskogo Otdelenia Rossiiskoi Academii Nauk \\ [Buryat Scientific Center, Siberian Branch, Russian Academy of Sciences]. \\ Izd-vo IAE SO RAN - Izdatel'stvo Instituta Arheologii i Ètnografii Sibirskogo Otdeleniia Rossiiskoi \\ Academii Nauk [Publishing House of the Institute of Archaeology and Ethnography, Siberian \\ Branch, Russian Academy of Sciences].
}




\section{Bibliography}

Afanas'eva-Medvedeva, G. 2007 Slovar' govorov Russkih Starozhilov Baikal'skoi Sibiri: $v 20$ tomah [Dictionary of old inhabitants of the Baikal Siberia], vol. 1 (Irkutsk, Ministerstvo kul'tury i archivov Irkutskoi oblasti).

Anderson, D. \& N. Orekhova 2002 The Suslov legacy. The story of one family's struggle with shamanism, Sibirica 2(1), pp. 88-112.

Aleksandrov, V. A. 1964 Russkoe naselenie Sibiri v XVII-nachale XVIII v. (Eniseiskii krai) [The Russian population of Siberia in the $17^{\text {th }}$-beginning of $18^{\text {th }}$ century (Eniseiskii krai)] (Moscow, Nauka).

Alekseenko, E. A. 1986 Promyslovaia kul'tura korennogo naseleniia Turuhanskogo regiona [The hunting culture of indigenous population of the Turuhansk region], in Ch. Taksami (ed.), Kul'turnye traditsii narodov Sibiri (Leningrad, Nauka), pp. 57-94.

Basharov, I. P. 2005 Russkaia promyslovaia kul'tura Vostochnogo Pribaikal'ia (konets XIX-nachalo XX v.) [Russian hunting culture of the Eastern Pribaikal region (end 19 th-beginning of $20^{\text {th }}$ century] (Ulan-Ude, Izd-vo Buriatskii Nauchnyi Tsentr Sibirskogo Otdeleniia RAN).

Boiko V. I. \& V. G. Kostyuk (eds) 1992 Evenki basseina reki Enisei [The Evenki of the Enisei bassin] (Novosibirsk, Nauka).

Brodnikov, A. A. 2006 Russko-tungusskie vzaimootnosheniia na Lenskom voloke i prilegaiushchei territorii v 30-e gody XVII veka (do obrazovaniia Iakutskogo uezda) [The Russian-Tungus relationships in Lensk portage and close territories in the 1630' (before the establishment of the Yakutsk district], Vestnik Novosibirskogo Gosudarstvennogo Universiteta 3(1), pp. 12-19 [online, URL: http://www.nsu.ru/xmlui/handle/nsu/5611, accessed 6 October 2016].

Bunak, V. V. \& I. M. Zolotareva (eds) 1973 Russkie starozhily Sibiri. Istoriko-antropologicheskie ocherki [The Russian old residents of Siberia. A historical and anthropological monograph] (Moscow, Nauka).

Buraeva, O. V. 2005 Ètnokul'turnoe vzaimodeistvie narodov Baikal'skogo regiona v XVII-nachale XX v. [Ethno-cultural relationship of peoples in the Baikal Region in the 17th-beginning of $20^{\text {th }}$ century] (UlanUde, Izd-vo Buriatskii Nauchnyi Tsentr Sibirskogo Otdelenia RAN).

Chekaninskii, I. 1914 Sledy shamanskogo kul'ta v russko-tungusskih poseleniiah po reke Chune v Eniseiskoi gubernii [Signs of shamanic cult among the Russian-Tungus population along the River Chuna in the Eniseisk province], Ètnograficheskoe Obozrenie 3-4, pp. 61-80.

Davydov, V. N. 2013 Vlast' provodnika: kaiury-Evenki i ispol'zovanie olennogo transporta na Severnom Baikale [Guide power: kaiury-Evenki and a use of reindeer transport on the Northern Baikal], in V. A. Popov (ed.) Rannie formy potestarnyk system. (St. Petersburg, Muzei Antropologii i Ètnografii).

Dolgih, B. O. 1960 Rodovoi i plemennoi sostav narodov Sibiri [Clan and kin composition of peoples of Siberia] (Moscow, Nauka).

Dumont, A. (this volume) Are the Evenki reindeer herders still nomads? The alternate use of different types of spaces in Inner Mongolia, China, Études mongoles \& sibériennes, centrasiatiques \& tibétaines 49 [online, URL: http://journals.openedition.org/emscat/3398, accessed 20 December 2018].

Gemuev, I. N. \& A. N. Sagalaev 1986 Ètnicheskie kul'tury Sibiri. Problemy èvoliutsii i kontaktov [The ethnic cultures of Siberia. Questions on evolution and contacts] (Novosibirsk, Nauka, Sbornik nauchnyh trudov). 
Gemuev, I. N. \& A. A. Badmaev (eds) 2002 Problemy mezhètnicheskogo vzaimodeistviia narodov Sibiri [Questions on the inter-ethnical interactions between peoples of Siberia] (Novosibirsk, Izd-vo Instituta Arheologii i Ètnografii Sibirskogo Otdelenia Rossiiskoi Akademii Nauk).

Gurvich, I. S. \& B. O. Dolgih (eds) 1970 Obshchestvennyi stroi u narodov Severnoi Sibiri. XVII-nachalo XX v. [Social order among peoples of the Northern Siberia] (Moscow, Nauka)

Kaigorodov, A. M. 1968 Èvenki v Trëkhrech'e (po lichnym nabludeniiam) [The Evenki of the Three Rivers Area (on the personal observations)], Sovetskaia Ètnografiia 4, pp. 123-131.

1970 Russkie v Trëhrech'e (po lichnym vospominaniiam) [The Evenki of the Three Rivers area. (on the personal reminiscences)], Sovetskaia Ètnografiia 2, pp. 140-149.

Karih, E. V. 2004 Mezhètnicheskie otnosheniia v Zapadnoi Sibiri v protsesse ee hoziaistvennogo osvoeniia. XIX-nachalo XX v. [The inter-ethnical relationships in Western Siberia in the process of its economic colonisation. $19^{\text {th }}$-beginning of $20^{\text {th }}$ century] (Tomsk, Izd-vo Tomskogo Universiteta).

Hodukin, I. N. 1924 Tungusy reki Kochengi [The Tungus of the river Kochenga], Sbornik trudov professorov i prepodavatelei Irkutskogo gosudarstvennogo universiteta 8, pp. 365-391.

Kopylov, I. P., A. A. Pogudin \& N. I. Romanov 2009 Promyslovoe hoziaistvo tuzemnogo i russkogo naseleniia $v$ verhoviah Nizhnei Tunguski [The hunting-fishing economy of the indigenous and local population in the upper Lower Tunguska] (Irkutsk, IG SB RAS).

Kuzakov M. 1985 U sedogo kostra. Povesti i rasskazy [Close to the gray camp fire. Narratives] (Irkutsk, Vostochno-Sibirskoe knizhnoe izdatel'stvo).

Lindgren, E. J. 1938 An Example of Culture Contact without Conflict. Reindeer Tungus and Cossacks of Northwestern Manchuria, American Anthropologist 40(4), pp. 605-621.

Marhinin, V. V. 1993 Russkii ètnos v mezhètnicheskih vzaimodeistviiah: Programma issledovanii v regionah Sibiri [The Russian ethnos in the inter-ethnical interactions research program in the Siberian regions] (Novosibirsk, Institut Filosofii i Prava Sibirskogo Otdeleniia Rossiiskoi Akademii Nauk).

Novikova, N. I. \& Iu. Ia. Iakel'. 2006 Sudebnaia zashchita prava na traditsionnoe prirodopol'zovanie: antropologo-pravovye aspekty [Court defence of the right for traditional land uses: the juridical anthropology aspects] (Moscow, IEA RAS).

Patkanov, S. K. 1906 Opyt geografii i statistiki tungusskih plemen Sibiri (na osnovanii dannyh perepisi 1897 g. i drugih materialov) [Geographical and statistic experience of the Tungus groups of Siberia], Zapiski Imperatorskogo Russkogo Geograficheskogo Obshchestva po otdeleniiu ètnografii (Saint-Petersburg) 31(1), pp. 1-175.

1912 Statisticheskie dannye, pokazyvaiushchie plemennoi sostav naseleniia Sibiri, iazak i rody inorodtsev (na osnovanii dannyh spetsial'noi razrabotki materiala perepisi 1897 g.) [Statistic data showing tribal composition of Siberian population, language and clans of non-Russian population], Zapiski Imperatorskogo Russkogo Geograficheskogo Obshchestva po otdeleniiu statistiki (Saint-Petersburg) 11(3), pp. 433-1000.

Safonova, T. \& I. Santha 2013a Vstrechi na Èvenkiiskoi Zemle: Kiberneticheskaia Antropologiia Baikal'skogo Regiona [Culture contact in Evenki land. A cybernetic anthropology of the Baikal region] (Moscow, Aleteiia).

$2013 \mathrm{~b}$ Culture Contact in Evenki Land. A Cybernetic Anthropology of the Baikal Region (Leiden/Boston, Global Oriental).

Shishkov, V. Ia. 1985 S beregov Nizhnei Tunguski [From the riversides of Lower Tunguska] (Irkutsk, Vostochno-Sibirskoe knizhnoe izdatel'stvo, Strashnyi kam. Povesti, roman, rasskazy, ocherki). 
Sirina, A. 2006 Katanga Evenkis in the $20^{\text {th }}$ Century and the Ordering of their Life-World (Edmonton, CCI Press).

1993 Perezhitki traditsionnyh verovanii u Nizhnetungusskih Evenkov [Remnants of traditional believes among the Evenk of Lower Tunguska], Rossiiskii ètnograf, pp. 187-202.

2009. The Taiga Hunters after perestroika (the case study of the Evenki of Irkutsk Oblast' eastern Siberia), in H. Beach, D. Funk \& L. Sillanpaa (eds), Post-Soviet Transformations and Politics of Ethnicity and Resource Use in Russia (Uppsalla, Univ. Publications), pp.137-160.

Slezikin, Iu. 2008 Arkticheskie zerkala. Rossiia i malye narody Severa [The Arctic mirors. Russia and the small peoples of the North] (Moscow, Novoe Literaturnoe Obozrenie).

1994 Arctic Mirrors. Russia and the Small Peoples of the North (Ithaca/London, Cornell University Press).

Strakach, Iu. B. 1962 Èvenkiisko-Russkaia promyslovaia artel' "Pobeda" [The Evenk-Russian hunting artel 'Pobeda'], Sibirskii ètnograficheskii sbornik 4, pp.122-136.

Vasilevich, G. M. 1930. Tokminskie Tungusy [The Tungus of Tokma], Sovetskii Sever 5, pp. 27-38. n.d. O Tungusah Irkutskoi gubernii [The Tungus people of Irkutsk Governmental Territory], Gosudarstvennyi arhiv Irkutskoi oblasti (Irkutsk State Regional Archive) 565/1/61, p. 9. 1958. Èvenkiisko-russkii slovar' [Evenki-Russian dictionary] (Moscow, Gosudarstvennoe izdatel'svto inostrannyh i natsional'nyh slovarei).

1969. Èvenki. Istoriko-ètnograficheskie ocherki (XVIII-nachalo XX v.) [The Evenki. Historical and ethnographic monograph (18 $8^{\text {th }}$-beginning of $20^{\text {th }}$ centuries)] (Leningrad, Nauka).

Wure'ertu (this volume) Evenki migrations in early times and their relationship with rivers, Études mongoles \& sibériennes, centrasiatiques \& tibétaines 49 [online, URL: http://

journals.openedition.org/emscat/3196, accessed 20 December 2018].

Xie, Y. (this volume) From hunters to herders. Reflections on the "Ecological Migration" of the Chinese Evenki reindeer herders, Études mongoles \& sibériennes, centrasiatiques \& tibétaines 49 [online, URL: http://journals.openedition.org/emscat/3414, accessed 20 December 2018].

\section{NOTES}

1. They are known as "Katangskii" Evenki after the name of the district in Irkutsk Oblast' where the Nizhniaia (Lower) Tunguska is situated.

2. According to the archival data, in 1887, there were 55 deportees of only Russian Orthodox faith, with an average age of 35 years, in Preobrazhenskaia district (Ru. volost') in Kirenskii county (Ru. okrug) (ISRA 50/1/176, p. 35).

3. By the end of the $19^{\text {th }}$ century some 60 deportees - Jews, Russians, Ukrainians, Poles etc. - were living along the river Lower Tunguska.

4. List of families residing in a specific parish with information about communion.

5. This is a hybrid word since the Evenki word kachikan means puppy, to which was added a Russian diminutive suffix $-k a$ (singular), or $-k i$ (plurial) [note from editor Lavrillier].

6. This word is used by both the Evenki and old Russians. It comes probably from the Yakut word saryy - chamois leather. In Evenk sari means also long elk leather shoes (in the Yakut fashion) (Vasilevich 1958, p. 345). 


\section{ABSTRACTS}

This article explores ethno-cultural contacts between Evenki (Tungus) and old Russian settlers in the upper flow of the river Lower Tunguska. The article is based on the rich regional and local archival sources, as well as on the author's field data. The author gives a brief history of colonisation of the region, restores the number of groups in contact and their composition, investigates the economic and cultural features of both groups and interactions between them, shows the perception of Evenki by local Russians. The main channel for contacts between these two ethnic groups was hunting. The process of acculturation was not one-sided and has formed a peculiar regional population. The deep social transformations of Soviet and post-Soviet periods were not able to obliterate what unifies the local population: the deep-set memory of their historical past and hunting as an occupation and way of life.

Cet article étudie les contacts culturels entre les Évenks (Toungouses) et les Russes anciennement installés sur le cours supérieur de la rivière Toungouska Inférieure. Fondé sur les matériaux nombreux et riches des archives régionales et locales, ainsi que sur les données de terrain de l'auteur, il propose une brève histoire de la colonisation de la région, et reconstitue les compositions des groupes en contact ainsi que leur nombre. L'article examine par ailleurs les caractéristiques économiques et culturelles des différents groupes russes et évenks, ainsi que leurs interactions essentiellement autour de la chasse. Cet article étudie également la perception qu'ont les Russes locaux des Évenks. Le processus d'acculturation n'a pas fonctionné à sens unique et a généré l'apparition d'une population locale assez particulière. L'auteur montre que les profondes transformations sociales apportées pendant et après la période soviétique ne sont pas venues à bout de deux éléments importants qui assurent la cohésion de la population locale, à savoir d'une part, la mémoire profondément ancrée d'une histoire commune et, d'autre part, la chasse comme activité et mode de vie.

\section{INDEX}

Mots-clés: ethnohistoire, relations inter-ethniques, Sibérie, Évenk, Russe, colonisation, perception, chasse, métis

Keywords: ethnohistory, interethnic relationship, Siberia, Evenki, Russian, colonisation, perception, hunting, metis

\section{AUTHORS}

\section{ANNA A. SIRINA}

Anna A. Sirina received her Dr Sc. (Habilit. and PhD) in Ethnology and Anthropology from the Institute of Ethnology and Anthropology at the Russian Academy of Sciences (2011). She works as a leading research fellow at the Department of Northern and Siberian Studies, Institute of Ethnology and Anthropology (Russian Academy of Sciences). She has been conducting frequent fieldworks in Siberia since 1981. She is the author and the editor of numerous books, book chapters, and peer-reviewed articles on history of anthropology and on various aspects of cultures of indigenous peoples and Old Russian settlers of Siberia, including Evenki in the $20^{\text {th }}$ century (2006) and Evenki i èveny $v$ sovremennom mire [Evenki and Eveny in the modern world. 
Identity, nature use and world view] (2012, in Russian).

annas@iea.ras.ru 